\title{
VARIATION IN WEED INFESTATION OF SUGAR BEET (Beta vulgaris L. subsp. vulgaris) DEPENDING ON THE INTENSITY OF CHEMICAL PROTECTION OF PLANTATIONS
}

\author{
Krzysztof Domaradzki, Katarzyna Marczewska-Kolasa, Marcin Bortniak \\ Institute of Soil Science and Plant Cultivation, National Research Institute \\ Department of Weed Science and Tillage Systems, Orzechowa 61, 50-540 Wrocław \\ e-mail: k.domaradzki@iung.wroclaw.pl
}

Received: 20.04.2013

\section{Abstract}

A floristic study was conducted over the period 2010 2012, using the Braun-Blanquet method, under which vegetation relevés were made in sugar beet (Beta vulgaris L. subsp. vulgaris) plantations in Lower Silesia. Fields with similar habitat conditions, which differed in the intensity of herbicide application to control weed infestation, were selected for observation. A total of 144 relevés were made and based on them a list was prepared of species found in fields in which different levels of chemical protection were used. A cover index and a constancy class were determined for each species found in the phytocoenoses studied.

On the basis of these observations, the study found floristic variation in the investigated agrophytocenoses as affected by the level of intensity of weed control chemicals used. In herbicide-untreated plots, a total of 25 weed species were found and their aggregate cover index was 8705. Chenopodium album L., Polygonum persicaria L. and Setaria pumila (POIR.) ROEM. \& SCHULT by far dominated among them. Herbicide use caused an impoverishment in the floristic list. 20 taxa were observed in the plots treated with the lowest herbicide rates, while with increasing rates the number of species dropped to 18. The sum of the cover indices also decreased with increasing rates, successively reaching the values of 5907, 5212 and 4356.

Key words: Beta vulgaris L. subsp. vulgaris, weeds, herbicides, cover index, constancy, rates

\section{INTRODUCTION}

Due to its cultivation with wide row spacing and its low competitive ability, sugar beet belongs to plants very susceptible to weed infestation. Therefore, from the agricultural point of view, it is important to keep a sugar beet plantation free from weeds as long as possible [1]. For many years, weed control in sugar beet crops has been based on the application of herbicides as part of systemic treatments. They predominantly involve 3-4 treatments performed using foliar-active herbicides to control weeds at very early growth stages [2-4]. By taking advantage of the high sensitivity of young weeds, it is also possible to substantially reduce herbicide rates and to use properly selected herbicide mixtures at rates reduced by at least 50\% [5-8].

The aim of the present study was to evaluate the effect of weed control systems used in sugar beet crops at different intensity levels on the floristic diversity of sugar beet agrophytocenoses in Lower Silesia.

\section{MATERIALS AND METHODS}

A floristic study was conducted over the period 2010-2012, using the Braun-Blanquet method, under which vegetation relevés were made in sugar beet (Beta vulgaris L. subsp. vulgaris) plantations in Lower Silesia. Fields with similar habitat conditions (black earths, agricultural land suitability classes 1 and 2), which differed in the intensity of herbicide application to control weed infestation, were selected for observation. In the evaluated fields, weed infestation was analyzed in control (herbicide-untreated) plots and herbicide-treated plots. In each plantation, herbicides were applied in $20 \mathrm{~m}^{2}$ plots. Mixtures consisting of three herbicides and an adjuvant were used in the investigations. Each mixture always included herbicides that contained: (phenmedipham $=91 \mathrm{~g} / \mathrm{l}+$ desmedipham $=$ $71 \mathrm{~g} / \mathrm{l}+$ ethofumesate $=112 \mathrm{~g} / \mathrm{l}$ ) and (triflusulfuronmethyl $=50 \%$ ), and an adjuvant (ethoxylated isodecyl $=90 \%$ ); they were supplemented by adding agents that contained $($ metamitron $=70 \%)$ or $($ lenacil $=80 \%)$.

The variation in the intensity of chemical protection resulted from the use of different levels of 
herbicides which were applied at three rates: the full rate $(100 \%)$ and two reduced rates (by 50\% and 67\% relative to the full rate). In accordance with good plant protection practices, herbicide treatment was always performed four times. Weed control efficacy was not analyzed depending on herbicide used, but the study focused on the determination of the effect of the intensity of chemical protection (as expressed by herbicide rate) on communities occurring in sugar beet.

A total of 144 relevés were made and based on them a list was prepared of species found in the fields where different levels of chemical protection were used. On the basis of relevés obtained, constancy (C) and a cover index (CI) were determined for the observed species [9].

One-way analysis of variance was used for statistical evaluation of the results. Due to large variation in the cover indices expressed in percent, for calculations these values were transformed using the following formula:

$$
\mathrm{y}=\arcsin \sqrt{ } \mathrm{x}
$$

\section{RESULTS}

Weed infestation in the sugar beet plantations evaluated was clearly dependent on the intensity of chemical protection. A total of 25 weed species were found to occur in the herbicide-untreated plots. The highest abundance was observed for Chenopodium album, which was a constant component of the phytocoenosis and the cover index for this species was 3908. Echinochloa crus-galli, Amaranthus retroflexus and Solanum nigrum were included in frequent species (constancy class IV). It should be added, however, that their cover indices were low and ranged from 10 to 51. Among medium frequent species, only two taxa were observed: Brassica napus ssp. napus and Polygonum lapathifolium ssp. lapathifolium, and they were characterized by a cover index of 756 and 300, respectively. Infrequent species $(\mathrm{C}=\mathrm{II})$ were represented by 5 taxa; their cover indices varied markedly and they were 1503 and 1547 for Polygonum persicaria and Setaria pumila, respectively, through 133 for Cirsium arvense, down to 10 for Galium aparine and Viola arvensis. 14 species characterized by a minimal cover index were included in rare components of the phytocoenoses. The overall weed infestation in the herbicide-untreated plots was very high. The sum of the cover indices was close to maximum -8705 (Table 1).

The observations made in the herbicide-treated plots where the rate reduced by $67 \%$ was used revealed a decrease in the sum of the cover indices of all taxa to 5907. One constant component was found in the agrophytocenosis - Chenopodium album - and its cover index was 1365 . There was also only one species in constancy class IV, which was Echinochloa crus-galli
(CI=145). The next four taxa - Amaranthus retroflexus, Solanum nigrum, Polygonum lapathifolium ssp. lapathifolium and Setaria pumila - were included in medium frequent components $(\mathrm{C}=\mathrm{III})$. Their cover indices ranged between 191 and 1308. Another six species, i.e. Brassica napus ssp. napus, Polygonum persicaria, Galium aparine, Cirsium arvensis, Aethusa cynapium and Fallopia convolvulus, were classified in constancy class II. Their cover indices varied, ranging from 10 to 741 . The remaining 8 taxa occurred sporadically, reaching minimal values of the cover index. 5 species observed in the unweeded plots were not found to occur in this treatment (Table 1).

The use of herbicides at a rate reduced by $50 \%$ caused a further decrease in weed infestation. The sum of the cover indices of the species found at these sites was 5212. A total of 18 taxa were found to occur in them. In this case, there was also only one species (Chenopodium album) in constancy class $\mathrm{V}$ and its cover index was 1026. Only one taxon was also distinguished among frequent components $(\mathrm{C}=\mathrm{IV})$ of the phytocoenosis. This was Echinochloa crus-galli, which was characterized by a low cover index (93). The following belonged to medium frequent species (C=III): Amaranthus retroflexus, Polygonum lapathifolium ssp. lapathifolium and Setaria pumila, and their cover indices ranged between 275 and 1239. Solanum nigrum, Polygonum persicaria, Galium aparine, Cirsium arvensis, Aethusa cynapium and Fallopia convolvulus were classified in constancy class II. The cover indices of these species ranged from 50 to 500 . The other 7 species occurred sporadically and had low cover indices (Table 1).

18 weed species were found to occur in the herbicide-treated plots where the full herbicide rate $(100 \%)$ was used. The level of weed infestation was distinctly lower compared to the sites where herbicides were used at lower rates, and the sum of the cover indices was 4356. Based on phytosociological analysis, only Chenopodium album could be included in constant species (constancy class V), whereas in frequent taxa (constancy class IV) only Echinochloa crus-galli; their cover indices were 679 and 32, respectively. In the evaluated plots, 3 species belonging to constancy class III were found, Amaranthus retroflexus, Solanum nigrum and Polygonum lapathifolium ssp. lapathifolium, and their cover indices ranged from 378 to 1440. Among other species, 6 taxa (Brassica napus ssp. napus, Polygonum persicaria, Setaria pumila, Galium aparine, Aethusa cynapium and Fallopia convolvulus) were classified as infrequent species (C=II) and they were characterized by a cover index in the range from 51 to 399 . The remaining 7 taxa were observed sporadically (Table 1).

Analyzing the results in statistical terms, it can be concluded that the total weed infestation in the 
herbicide-untreated plots was significantly higher than in the plots with chemical weed control. The situation varied greatly between individual species. Regardless of the rate applied, herbicide use caused a significant reduction in weed infestation with dominant species, which were Chenopodium album, Brassica napus ssp. napus, Polygonum persicaria and Setaria pumila. As a result of the elimination of these species, some taxa occurring in low abundance, such as Amaranthus retroflexus, Solanum nigrum, Polygonum lapathifolium ssp. lapathifolium, Galium aparine and Fallopia convolvulus, when not influenced by the competitive effects of the dominants, replaced them and increased their cover indices (CI) at the herbicide-treated sites. However, it should be clearly stated that this increase, even though proven to be statistically significant, was low and not dangerous to the crop plant from the practical point of view. In the case of the other species, no significant differences were found in their abundance as affected by the intensity of herbicide application (Table 1).

Table 1

Weed infestation of sugar beet depending on the intensity of chemical protection of plantations (based on 144 relevés from the period 2010-2012).

\begin{tabular}{|c|c|c|c|c|c|c|c|c|}
\hline \multirow{2}{*}{ Weed species } & \multicolumn{2}{|c|}{$\begin{array}{l}\text { Unweeded } \\
\text { plots }\end{array}$} & \multicolumn{2}{|c|}{$\begin{array}{l}33 \% \text { herbicide } \\
\text { rate }\end{array}$} & \multicolumn{2}{|c|}{$\begin{array}{l}50 \% \text { herbicide } \\
\text { rate }\end{array}$} & \multicolumn{2}{|c|}{$\begin{array}{l}100 \% \text { herbicide } \\
\text { rate }\end{array}$} \\
\hline & $\mathrm{CI}$ & $\mathrm{C}$ & $\mathrm{CI}$ & $\mathrm{C}$ & $\mathrm{CI}$ & $\mathrm{C}$ & $\mathrm{CI}$ & $\mathrm{C}$ \\
\hline Chenopodium album $\mathrm{L}$. & $3908 \mathrm{a}$ & $\mathrm{V}$ & $1365 \mathrm{~b}$ & $\mathrm{~V}$ & $1026 \mathrm{~b}$ & $\mathrm{~V}$ & $679 \mathrm{~b}$ & $\mathrm{~V}$ \\
\hline Echinochloa crus-galli (L.) P.BEAUV. & $51 \mathrm{a}$ & IV & $145 \mathrm{a}$ & IV & $93 \mathrm{a}$ & IV & $32 \mathrm{a}$ & IV \\
\hline Amaranthus retroflexus L. & $10 \mathrm{~b}$ & IV & $383 \mathrm{a}$ & III & $275 \mathrm{a}$ & III & $378 \mathrm{a}$ & III \\
\hline Solanum nigrum L. EMEND. MILL. & $10 \mathrm{~b}$ & IV & $191 \mathrm{a}$ & III & $179 \mathrm{a}$ & II & $255 \mathrm{a}$ & III \\
\hline Brassica napus L. ssp. napus & 756 a & III & $191 \mathrm{~b}$ & II & $50 \mathrm{~b}$ & I & $144 \mathrm{~b}$ & II \\
\hline Polygonum lapathifolium L. ssp. lapathifolium & $300 \mathrm{~b}$ & III & 1308 a & III & 1239 a & III & $1440 \mathrm{a}$ & III \\
\hline Polygonum persicaria $\mathrm{L}$. & $1547 \mathrm{a}$ & II & $59 \mathrm{~b}$ & II & $200 \mathrm{~b}$ & II & $194 \mathrm{~b}$ & II \\
\hline Setaria pumila (POIR.) ROEM. \& SCHULT. & $1503 \mathrm{a}$ & II & $191 \mathrm{~b}$ & III & $575 \mathrm{~b}$ & III & $51 \mathrm{~b}$ & II \\
\hline Cirsium arvense (L.) SCOP. & $133 \mathrm{a}$ & II & $10 \mathrm{a}$ & $\mathrm{I}$ & $50 \mathrm{a}$ & I & $10 \mathrm{a}$ & I \\
\hline Galium aparine $\mathrm{L}$. & $10 \mathrm{~b}$ & II & $741 \mathrm{a}$ & II & $307 \mathrm{a}$ & II & $399 \mathrm{a}$ & II \\
\hline Viola arvensis MURRAY & $10 \mathrm{a}$ & II & $10 \mathrm{a}$ & I & $50 \mathrm{a}$ & I & $10 \mathrm{a}$ & I \\
\hline Convolvulus arvensis L. & $337 \mathrm{a}$ & $\mathrm{I}$ & $554 \mathrm{a}$ & II & $418 \mathrm{a}$ & II & $173 \mathrm{a}$ & I \\
\hline Abutilon theophrasti MEDIK. & $10 \mathrm{a}$ & I & $10 \mathrm{a}$ & I & - & - & $10 \mathrm{a}$ & I \\
\hline Aethusa cynapium $\mathrm{L}$. & $10 \mathrm{a}$ & I & $10 \mathrm{a}$ & II & $50 \mathrm{a}$ & II & $173 \mathrm{a}$ & II \\
\hline Anagallis arvensis L. & 10 & I & - & - & - & - & - & - \\
\hline Elymus repens (L.) GOULD & $10 \mathrm{a}$ & I & $10 \mathrm{a}$ & I & $50 \mathrm{a}$ & I & - & - \\
\hline Geranium pusillum BURM. F. EX L. & $10 \mathrm{a}$ & I & $10 \mathrm{a}$ & I & $50 \mathrm{a}$ & I & $10 \mathrm{a}$ & I \\
\hline Matricaria maritima L. ssp. inodora (L.) DOSTSÁL & $10 \mathrm{a}$ & I & $10 \mathrm{a}$ & I & - & - & - & - \\
\hline Polygonum aviculare $\mathrm{L}$. & $10 \mathrm{a}$ & I & $55 \mathrm{a}$ & I & $50 \mathrm{a}$ & I & $133 \mathrm{a}$ & I \\
\hline Fallopia convolvulus (L.) Á. LÖVE & $10 \mathrm{~b}$ & I & $644 \mathrm{a}$ & II & $500 \mathrm{a}$ & II & $255 \mathrm{a}$ & II \\
\hline Lathyrus tuberosus L. & 10 & I & - & - & - & - & - & - \\
\hline Centaurea cyanus L. & 10 & I & - & - & - & - & - & - \\
\hline Papaver rhoeas $\mathrm{L}$. & 10 & I & - & - & - & - & - & - \\
\hline Stellaria media (L.) VILL. & 10 & $\mathrm{I}$ & - & - & - & - & - & - \\
\hline Veronica hederifolia L. S. STR. & $10 \mathrm{a}$ & I & $10 \mathrm{a}$ & I & $50 \mathrm{a}$ & I & $10 \mathrm{a}$ & I \\
\hline Sum of cover indices & $8705 \mathrm{a}$ & & $5907 \mathrm{~b}$ & & $5212 \mathrm{~b}$ & & $4356 \mathrm{~b}$ & \\
\hline
\end{tabular}

$\mathrm{CI}$ - cover index, $\mathrm{C}$ - constancy

$\mathrm{V}$ - constant components; IV - frequent components; III - medium frequent components; II - infrequent components; I - rare or sporadic components

$\mathrm{a}$ and $\mathrm{b}$ - values marked with the same letter do not differ significantly 


\section{DISCUSSION}

The floristic analysis allows us to conclude that in the evaluated segetal communities without herbicide weed control, located in Lower Silesia, the following taxa occurred most frequently: Chenopodium album, Echinochloa crus-galli, Amaranthus retroflexus, Solanum nigrum, Brassica napus ssp. napus, and Polygonum lapathifolium ssp. Lapathifolium, reaching the three highest levels of constancy (Table 1). Most of these taxa also pose a threat to sugar beet crops in other regions of the country. This is confirmed by the research conducted in Wielkopolska (Greater Poland) [10], Opolszczyzna (Opole region) [11], Mazowsze (Mazovia) [12], Mazury (Masuria) [13], and Podlasie [14]. Among the above-mentioned species, only Chenopodium album and Brassica napus ssp. napus reached significant (from the agricultural point of view) cover indices. As regards infrequent components of the phytocoenoses, Polygonum persicaria and Setaria pumila showed similar values.

Herbicide use had a significant effect on reducing the total weed infestation in the sugar beet plantations, compared to the unweeded plots. With increasing herbicide rate, the total ground cover by weeds decreased and their condition was poorer. Based on their research on sugar beet crops, W e s o ł ow s ki [15] as well as Deveikyte and Seibutis [16] came to similar conclusions.

In the case of some weed species, their cover indices were observed to increase in the chemically weeded plots compared to the herbicide-untreated sites. This particularly applied to Polygonum lapathifolium ssp. lapathifolium, Fallopia convolvulus and Amaranthus retroflexus, while to a lesser extent also to Solanum nigrum, Galium aparine and Polygonum aviculare. This was attributable to two factors. Firstly, due to the action of herbicides there was a significant reduction in the occurrence of the dominant species with very high competitive strength, notably Chenopodium album. Secondly, the chemical agents used were not fully effective in relation to the above-mentioned species and they could occupy a part of the released ecological niche. Such phenomena of mutual competition and interspecific interactions between the components of segetal communities have been the object of research and have been confirmed in the studies of Weiner [17], Weigelt and Jolliffe [18], $\mathrm{V}$ i 1 à et al. [19], and O k s a n e n a et al. [20]. Moreover, according to some authors, a single species occurring in high abundance exerts a greater negative effect on a cultivated plant than a multi-species community without clearly dominant species [21-23].

It is worth noting that several warmth-loving species were observed in the evaluated communities. Apart from the frequent components of the phytocoe- noses, such as Echinochloa crus-galli, Amaranthus retroflexus or Solanum nigrum, these were also Aethusa cynapium and Abutilon theophrasti. The occurrence of the latter species in the sugar beet plantations is particularly worth noting. The first information concerning the appearance of this taxon in Poland can be found in the paper by Rostafinski and Sowa [24] in which this species is reported (after other researchers) to occur in Wielopolska, Opole region, Kraków, Łódź and Siemianowice Śląskie. However, this information relates to ruderal sites, among others urbanized areas, railway tracks, and the surroundings of warehouses. In crop fields, A. theophrasti was first detected 13 years ago [25]. Since that time, it has been continually expanding its range, and though it occurs sporadically and reaches minimal cover indices, but it should be presumed that in the future it will become a frequent component of phytocoenoses, similarly as it happened in other countries [26-31].

To sum up, it can be stated that with increasing intensity of herbicide application a reduction in total weed infestation was observed (the sum of the cover indices declined). Furthermore, some species in the herbicide-treated plots reached higher cover indices than in the unweeded plots, since the competitive pressure of the dominant species in the community decreased and also not all herbicides used had a full effect on these species.

\section{CONCLUSIONS}

1. The level of weed infestation in the sugar beet plantations was dependent on the intensity of chemical protection in these plantations.

2. Increasing herbicide rates caused a decrease in total ground cover by weeds.

3. Herbicides, regardless of the rate used, caused a significant reduction in weed infestation by dominant species.

4. Some taxa occurring in low abundance, when not influenced by the competitive effects of the dominants, increased their cover indices, but this increase was slight and did not pose a threat to the crop plant from the practical point of view.

\section{Acknowledgments}

This study was conducted as part of task 2.6 under a long-term program carried out by the Institute of Soil Science and Plant Cultivation, National Research Institute.

\section{Authors' contributions}

The following declarations about authors' contributions to the research have been made: development of research assumptions and experimental designs:KD; 
performance of phytosociological analysis: KM-K, $\mathrm{MB}$; processing and analysis of results as well as preparing the manuscript for print: KD.

\section{REFERENCES}

1. Adamczewski K, Kawczyński J. Efektywność zwalczania chwastów w burakach cukrowych herbicydami składającymi się z kilku substancji aktywnych. Pr Nauk Inst Ochr Roślin. 1987; 28(1-2): 379-388.

2. Paradowski A, Adamczewski K. Ocena wpływu zmiany technologii odchwaszczania buraka cukrowego na przestrzeni 15 lat. Biul IHAR. 2002; 222: 271-277.

3. Rola J, Rahban BA, Marczewski K. Porównanie systemów chemicznego odchwaszczania buraków cukrowych. In: Materiały 34. Sesji Nauk Inst Ochr Roślin. 1994; 1: 96-103.

4. Wils on RG. New herbicides for postemergence application in sugar beet (Beta vulgaris). Weed Technol. 1994; 8: 807-811.

5. Dexter AG. History of sugar beet (Beta vulgaris) herbicide rate reduction in North Dakota and Minnesota. Weed Technol. 1994; 8: 334-337.

6. Domaradzki K. Optymalizacja stosowania herbicydów w systemach chemicznej ochrony buraka cukrowego [Optimisation of herbicide application in the sugar beet protection system]. Prog Plant Prot Post Ochr Roślin. 2007; 47(3): 64-73.

7. Wilson RG, Smith JA, Yonts CD. Repeated reduced rates of broadleaf herbicides in combination with methylated seed oil for postemergence weed control in sugar beet (Beta vulgaris). Weed Technol. 2005;19(4):855-860. http://dx.doi.org/10.1614/WT-04-258R1.1

8. Woźnica Z, Adamczewski K, Szeleźniak E. Stosowanie mikrodawek herbicydów w uprawie buraka cukrowego. Prog Plant Prot Post Ochr Roślin. 2004; 44: 523-530.

9. Pawłowski B. Skład i budowa zbiorowisk roślinnych oraz metody ich badania. In: Szafer W, Zarzycki K, editors. Szata roślinna Polski. Warsaw: Polish Scientific Publishers PWN; 1972. p. 237-269. (vol 1).

10. Latowski K, Czarna A. Florystyczne cechy zachwaszczenia wtórnego upraw buraka i ziemniaka na przykładzie wybranych regionów Zachodniej Polski. In: Materiały XXI Krajowej Konferencji Naukowej z cyklu: „Rejonizacja chwastów segetalnych w Polsce”, Wrocław, 22-23.09.1997. Puławy: Wyd IUNG; 1997. p. 23-35.

11. Kuźniewski E. Aktualne wtórne zachwaszczenie plantacji roślin okopowych na Dolnym Śląsku. In: Materiały XXI Krajowej Konferencji Naukowej z cyklu: „Rejonizacja chwastów segetalnych w Polsce”, Wrocław, 22-23.09.1997. Puławy: Wyd IUNG; 1997. p. 37-41.

12. Łęgowiak Z, Wysmułek A. Zachwaszczenie wtórne roślin ze szczególnym uwzględnieniem buraka cukrowego. In: Materiały XXI Krajowej Konferencji Naukowej z cyklu: „Rejonizacja chwastów segetalnych w Polsce”, Wrocław, 22-23.09.1997. Puławy: Wyd IUNG; 1997. p. 53-59.
13. Rychcik B, Tyburski J. Wpływ herbicydu i następstwa roślin na zachwaszczenie buraka cukrowego [Effect of herbicide and crop sequence on weed infestation of sugar beet]. Prog Plant Prot Post Ochr Roślin. 2009; 49(3): $1375-1378$.

14. Skrzyczyńska J, Skrajna T. Zachwaszczenie upraw roślin okopowych w środkowej części Równiny Bielskiej. In: Materiały XXI Krajowej Konferencji Naukowej z cyklu: „Rejonizacja chwastów segetalnych w Polsce", Wrocław, 22-23.09.1997. Puławy: Wyd IUNG; 1997. p. 61-68.

15. We s ołowski M. Fruiting phenology of some weed species in sowing of chosen cultivar plants. Acta Agrobot. 2006; 59(2): 335-344. http://dx.doi.org/10.5586/aa.2006.087

16. Deveikyte I, Seibut is V. Broadleaf weeds and sugar beet response to phenmedipham, desmedipham, ethofumesate and triflusulfuron-methyl. Agron. Reasearch. 2006; 4: 159-162.

17. Weiner J. Competition among plants. Treb SCB. 1993; 44: 99-109.

18. Weigelt A, Jolliffe P. Indices of plant competition. J Ecol. 2003; 91(5): 707-720. http://dx.doi.org/10. 1046/j.1365-2745.2003.00805.x

19. Vilà M, Williamson M, Lonsdale M.Competition experiments on alien weeds with crops: lessons for measuring plant invasion impact? Biol Invasions. 2004; 6(1): 59-69. http://dx.doi.org/10.1023/B:BINV.0000010122.770 $24.8 \mathrm{a}$

20. Oksanen L, Sammul M, Mägi M. On the indices of plant-plant competition and their pitfalls. Oikos. 2006; 112(1): 149-155. http://dx.doi.org/10.1111/j.0030-12 99.2006.13379.x

21. Adamczewski K. Chemiczna walka z chwastami na przestrzeni ubiegłych 25 lat i kierunki dalszego rozwoju herbologii. In: Materiały 25. Sesji Nauk Inst Ochr Roślin. 1985; 1: 95-114.

22. Rola J. Ekologiczno-ekonomiczne podstawy chemicznej walki z chwastami na polach uprawnych. In: Materiały 31. Sesji Nauk Inst Ochr Roślin. 1991; 1: 110-124.

23. Wils on B J. Yield responses of winter cereals to the control of broadleaved weeds. In: Proc EWRS Symposium. Stuttgard: 12-14.03.1986: 75-82.

24. Rostafiński K, Sowa R. Alfabetyczny wykaz efemerofitów Polski. Fragm Flor Geobot. 1986; 1-2: 151-205.

25. Domaradzki K, Snopczyński T, JezierskaDom a radzka A. Zaślaz pospolity (Abutilon theophrasti Medik.), nowy groźny chwast upraw polowych - charakterystyka występowanie i możliwości zwalczania [Abutilon Theophrasti Medik., new dangerous weed - characterization, appearance and control possibilities]. Prog Plant Prot Post Ochr Roślin. 2008; 48: 567-574.

26. Spencer NR. Velvetleaf, Abutilon theoprasti (Malvaceae), history and economic impact in the United States. Econ Bot. 1984; 38(4): 407-416. http://dx.doi.org/10.1007/ BF02859079

27. Pyšek P, Sádlo J, Mandák B. Catalogue of alien plants of the Czech Republic. Preslia. 2002; 74: 97-186. 
28. Jursík M, Soukup J, Holec J. Herbicide control of velvetleaf (Abutilon theophrasti) in sugar beet. Herbologia. 2004; 5(1): 13-21.

29. Doncila AI. Retrospection concerning the sugar beet protection on Fundulea zone, district Calarasi, Romania. Proc Nat Sci. 2006; 110: 141-149. http://dx.doi.org/10. 2298/ZMSPN0610141D

30. Kovács I, Béres I, Kazinczi G, Torma M. Competition between maize and Abutilon theophrasti (Medik.) in additive experiments. J Plant Prot. 2006; 20: 767-771.

31. Mein $1 \mathrm{sch}$ midt E. Abutilon theophrasti MED. auf dem Ackerland in Sachsen - Ergebnisse des Monitorings aus den Jahren 2000-2004 und Handlungsempfehlungen. J Plant Prot. 2006; 20: 487-492.

\section{Zróżnicowanie zachwaszczenia buraka cukrowego \\ (Beta vulgaris L. subsp. vulgaris) w zależności od intensywności chemicznej ochrony plantacji}

\section{Streszczenie}

Badania florystyczne prowadzono w latach 2010-2012 metodą Braun-Blanquet'a, wykonując zdjęcia fitosocjologiczne na plantacjach buraka cukrowego na terenie Dolnego Śląska. Do obserwacji wybrano pola o podobnych warunkach siedliskowych, które różnicowała intensywność stosowania herbicydów do eliminacji zachwaszczenia. Łącznie wykonano 144 zdjęcia fitosocjologiczne, na podstawie których sporządzono listy gatunków występujących na polach o różnym poziomie chemicznej ochrony plantacji. Dla każdego gatunku występującego w badanych fitocenozach wyznaczono współczynnik pokrycia oraz klasę stałości fitosocjologicznej.

$\mathrm{Na}$ podstawie wykonanych obserwacji stwierdzono zróżnicowanie florystyczne badanych agrofitocenoz pod wpływem poziomu intensywności stosowania chemicznych środków chwastobójczych. Na powierzchniach nie chronionych herbicydami odnotowano występowanie ogółem 25 gatunków chwastów, których sumaryczny współczynnik pokrycia wynosił 8705 . Wśród nich zdecydowanie dominowały Chenopodium album L., Polygonum persicaria L. i Setaria pumila (POIR.) ROEM. \& SCHULT. Stosowanie herbicydów powodowało ubożenie listy florystycznej. W przypadku poletek traktowanych najniższymi dawkami środków ochrony obserwowano 20 taksonów, natomiast gdy dawki rosły liczba gatunków spadała do 18. Również suma współczynników pokrycia zmniejszała się wraz ze wzrostem dawki stosowanych środków, osiągając kolejno wartości 5907, 5212 i 4356.

Handling Editor: Elżbieta Pogroszewska

This is an Open Access digital version of the article distributed under the terms of the Creative Commons Attribution 3.0 License (creativecommons.org/licenses/by/3.0/), which permits redistribution, commercial and non-commercial, provided that the article is properly cited.

(CThe Author(s) 2014 Published by Polish Botanical Society 